International Journal of Environment, Agriculture and Biotechnology
Vol-6, Issue-4; Jul-Aug, 2021
JUEB
Journal Home Page Available: https://ijeab.com/
Journal DOI: $10.22161 /$ ijeab

\title{
Utilization of Biogas Sources from Pig Waste as an Effort to Minimize Environmental Pollution
}

\author{
Artise H.S. Salendu ${ }^{1, *}$, Meiske L. Rundengan ${ }^{1}$, Femi H. Elly ${ }^{1}$, Tilly F.D. Lumy ${ }^{1}$, D. \\ Polakitan $^{2}$
}

${ }^{1}$ Faculty of Animal Husbandry University of Sam Ratulangi Manado, North Sulawesi, Indonesia

${ }^{2}$ BPTP Kalasey, Manado, North Sulawesi, Indonesia

${ }^{*}$ Correspondence Author

Received: 20 Jun 2021; Received in revised form: 10 Jul 2021; Accepted: 21 Jul 2021; Available online: 28 Jul 2021

C2021 The Author(s). Published by Infogain Publication. This is an open access article under the CC BY license

(https://creativecommons.org/licenses/by/4.0/).

\begin{abstract}
Livestock was one of the subsectors that play an important role in human resource development. One of the livestock commodities that had an important role as a source of animal protein was pigs. North Sulawesi had prospects in the development of pigs in terms of livestock resources and the availability of local consumers. The problem was that pig farms were developed in residential areas so that this condition had a negative impact on the environment of the community. This research was conducted with the aim of analyzing the potential for biogas production from pig waste. The research method used was a survey method with a case study approach to pig farming. The location of pig farms was determined by purposive sampling, namely pig farms managed in residential areas. Respondents were the Maesa pig farmer group in Tempok Village. Analysis of the data used was descriptive analysis through the analysis of biogas production potential.The results showed that the number of pigs in the pen was 13 tails, consisting of adult and grower phases, each of which was 4, and the starter was 5. The total weight of pigs was 753 $\mathrm{kg}$ which produces $56.59 \mathrm{~kg}$ of manure per day. The results of this study had the potential to produce 1.53 $\mathrm{kg}$ of gas per day. Based on the results of the study, it can be concluded that the biogas produced was beneficial for minimizing environmental pollution and substituting the use of LPG gas and firewood. Suggestions, biogas reactors need to be socialized to other farmers who develop pig farming businesses in residential areas and need government intervention to introduce biogas reactors because they require investment funds.
\end{abstract}

Keywords-biogas, waste, pigs.

\section{INTRODUCTION}

Agricultural development is currently carried out with a sustainable orientation. Sustainable agriculture was a policy that was very much needed in development. The concept of a sustainable agricultural system was a concept that became a global issue that emerged in the eighties. Some evidence shows that agriculture as a production system was in fact also a polluter. Agriculture in a broad sense also includes the livestock sub-sector which was claimed to be a polluter. The livestock waste produced has an impact on increasing greenhouse gas emissions.
Livestock in North Sulawesi was generally a producer of animal protein food with high nutritional value to improve the quality of human resources. Livestock development in this case has good prospects in the future. This is because the current demand for livestock products continues to increase, along with the increase in population, income and public awareness to consume highly nutritious food. The indications are that livestock development needs to be encouraged in order to fulfill the demand of the population which tends to increase. The commodity of concern as a source of animal protein from livestock in North Sulawesi was pigs. 
Pigs were one of the livestock commodities that were relied on by some people of North Sulawesi as a source of animal protein as well as their source of income. This pig farming business had market prospects considering that the people of North Sulawesi province were potential consumers. Pig products in this area were liked and consumed by most people. This was supported by social and religious factors that support the community in consuming pork products so that the demand for pork was quite high.

The prospects described above were very supportive of the development of pigs which were supported by a very open market potential. The characteristics and abilities of these pigs provide benefits (Gobai et al, 2013), and their business development was very potential (Aku et al, 2013). This phenomenon shows that pigs were easy to sell at the age of 8-9 months with body weights reaching $100 \mathrm{~kg}$ live weight, balanced with fast growth, prolific nature (many births) and good ration efficiency. Pigs and or their processed products were quite potential as a national export commodity (Ministry of Agriculture, 2012). The market for pork commodities is even still wide open to various countries such as Singapore and Hong Kong. The advantage of pigs over chickens was that the volume of imports can be said to be zero (Ministry of Agriculture, 2012). Pigs based on several studies can be used as an alternative business for farmers because of the fairly high contribution of these businesses (Sobang and Paulus, 2017).

The production and population of pigs need to be encouraged in balancing their potential and development prospects. Based on the potential and prospects for the development of pig farming, the business can be increased to a commercial direction. Consequently, the increase in population and production of pigs had an impact on increasing pig waste.The increasing waste of pigs had the opportunity to pollute the environment. The production process of pig farming can cause environmental problems (Putra et al. 2015).Based on this problem, one way that can be done is to process pig manure into biogas. Biogas was a technology for the formation of energy (Wahyuni, 2011).he stages of the biogas process begin with building a biogas reactor to accommodate pig farm waste, which is very important in internalizing environmental pollution. Based on this background and thoughts, a research was conducted on the utilization of biogas from pig manure. The purpose of this study was to analyze the potential of biogas production and its benefits to pig farmers and society in general.

\section{RESEARCH METHODS}

The research method used was a survey method with a case study approach to pig farming. The data collected were primary data and secondary data. The location of the pig farm was determined by purposive sampling, namely the pig farm that was managed in a residential area. Respondents were the Maesa Pig Farmer Group in Tempok Village. The data analysis used was descriptive analysis through the analysis of biogas production potential using the formula (Wahyuni, 2015):

Biogas Production Potential $=\mathrm{BK} \times$ Production Rate $\left(\mathrm{m}^{3} / \mathrm{kg} \mathrm{BK}\right)$

Explanation :

BK : Dry Weight

Production Rate : $0.30 \mathrm{~m}^{3} / \mathrm{kg} \mathrm{BK}$ at $25^{\circ} \mathrm{C}$

\section{RESULTS AND DISCUSSION}

North Sulawesi as a potential area for the development of pigs can be seen from its population which was increasing every year. The pig population in 2018 was 411,753 heads to 427,777 in 2019 or an increase of 3.89 percent (BPS North Sulawesi, 2020). The increase in population was the impact of the increasing number of pig farming businesses, one of which was due to the potential of abundant natural resources and had not been fully utilized (Wea et al. 2020). The increase in the pig farming business was supported by the development of restaurants using pork as raw materials (Saroinsong et al. 2019).

Consequently, the increase in the population of pigs had an impact on environmental pollution. This was because the increasing population of pigs causes an increase in the amount of waste produced.The waste had an impact on environmental pollution of water, soil and air because it is not managed properly. Pig farm waste that was managed properly can had a positive impact, because the abundant livestock waste has the potential to be a source of energy that is very beneficial for farmers in particular and humans in general. The current condition of pig waste has been used as a source of biogas.

The results show that 100 percent of farmers develop pig farming as a source of income that is used to support the lives of farmers. However, livestock development was carried out in residential areas so that it was very disturbing to the surrounding community. Whereas farmers can benefit from the pig business (Suryadi et al. 2014).The pig business also has opportunities to compete in the MEA market (Suarna and Suryani, 2015). Pig farming has an impact on increasing income and employment opportunities if the management 
is carried out in accordance with the recommended and sustainable (Tulak et al. 2018).

The results showed that 75 percent of farmers graduated from junior high school and 25 percent graduated from high school. Farmers do not receive education about biogas and the use of biogas reactors. The lack of knowledge and low background of pig farmers cause environmental awareness has not beèn a concern.

Pig farm waste was channeled into thd.yard ardotpluBlody Weight of Pigs ( $\mathrm{Kg} / \mathrm{Day})$ drains. A biogas reactor was introduced in the wasearefoduced (Kg/Day) area in 2017 which was used as an example (Salendu et al. 2017). Pig farm waste had been channeled to a biogas (Kg/Day) reactor so that pollution can be minintized. In GaetProrkuction $\left(\mathrm{m}^{3} / \mathrm{kg} \mathrm{BK}\right)$ introduction of the biogas reactor had not been well received by other farmers and even by the government in the research area. Farmers and the government in general do not have knowledge about the benefits of building a biogas reactor. In addition, the construction of a biogas reactor requires investment funds so that it has not become the attention of farmers and various parties.

The results showed that the number of pigs managed by the Maesa group was 13 , consisting of 4 adult pigs, 4 growers and 5 starters. After weaning (aged 10 weeks), 36 pigs were immediately sold. Adult pigs belonging to farmers were used as broodstock. There were 13 pigs in the pen, which produce waste which was directly distributed to the biogas reactor. The biogas introduced in the research area was in the Maesa group farm (Salendu et al. 2017). The body weight of each pig was presented in Table 1.
The waste produced by breeder pigs with a body weight of 90-120 kg can reach $5.30 \mathrm{~kg}$ per day (Takarenguang et al. 2016). The biogas potential according to the research results can be seen in Table 2 .

Table 2.Biogas Production Potential

Description Valu

Table 1.Body Weight and Number of Pigs

\begin{tabular}{|c|c|c|c|c|c|c|}
\hline Body Weight (Kg) & Pigs(Ekor) & Amount (K & coso & $\begin{array}{l}\text { Ot Blogas Jrom Kese } \\
\text { Other Fus }\end{array}$ & 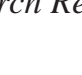 & nith \\
\hline 100 & 2 & & 200 & Production of $1 \mathrm{~m}^{3}$ & & \\
\hline 90 & $\mathrm{No}^{2}$ & Other Fuels & 180 & Biogas* & & Production of 1,53 \\
\hline 70 & 1.1 & LPG (kg) & 70 & & 0.46 & \\
\hline 65 & 2.2 & Kerosene (Liter) & 130 & & 0.62 & \\
\hline 50 & 3. 1 & Firewood $(\mathrm{Kg})$ & 50 & & 3.50 & \\
\hline 25 & $4 .^{2}$ & Diesel Oil (Liter) & 50 & & 0.52 & \\
\hline 20 & 5.2 & Gasoline (Liter) & 40 & & 0.80 & \\
\hline 15 & 6.1 & City Gas (Cubiv) & 15 & & 1.50 & \\
\hline
\end{tabular}

\begin{tabular}{llcl}
\hline To t a 13 & Keterangan $735 *$ *) Wahyuni (2015) \\
& & & $* *)$ Research Result Data (Processed)
\end{tabular}

There were 13 pigs with a total body weight of $735 \mathrm{~kg}$ (Table 1) which produce manure which was a potential source of biogas. The number of pigs totaling 36 heads in this case was considered not to affect biogas production because it had been sold.Making biogas can be done by farmers who had 6 pigs (Dewi and Kholik, 2018).
The total body weight of pigs according to the results of the study was $753 \mathrm{~kg}$ which produced $56.59 \mathrm{~kg}$ of waste per day (Table 2). This condition has the potential to produce $1.53 \mathrm{~kg}$ of gas per day. Pig feces was very good to use as stuffing material in the process of producing biogas because it has a feces $\mathrm{CN}$ ratio of 25 , meaning that the development and activity of methane-forming microorganisms is very good.Pigs are not only a producer of meat, organic fertilizer, but also biogas (Seseray et al. 2012). The biogas reactor was successfully constructed starting with pig manure (Adl et al. 2012). The implication was that pig farmers were able to substitute firewood and LPG gas with biogas produced from pig manure. Furthermore, the comparison of research biogas with other fuels was presented in Table 3 .
The results showed that the fuel used by farmers for their daily needs was LPG, kerosene and firewood. The data in Table 3 shows that the biogas production according to the research results was $1.53 \mathrm{~m} 3$ equivalent to $\mathrm{LPG}$ of 
$0.704 \mathrm{~kg}$ per day. The use of kerosene per day can be substituted by utilizing biogas, biogas production was 1.53 $\mathrm{m}^{3}$ equivalent to kerosene of 0.949 liters. Furthermore, the use of firewood per day can be substituted by utilizing biogas, biogas production of $1.53 \mathrm{~m}^{3}$ was equivalent to firewood of $5.355 \mathrm{~kg}$. The indication was that the cost of purchasing LPG gas and kerosene can be reduced if farmers use biogas from pig manure. Farmers can also reduce their use of firewood in the forest if they use biogas.

Household scale biogas technology was used as fuel for cooking instead of firewood and improves human health and the environment (Barnhart, 2012). Biogas was one type of energy and sustainable development that was important for energy and environmental planning. Biogas was one of the renewable energy sources that can answer the need for energy as well as provide soil nutrient needs in a sustainable agricultural system. The benefits obtained from making biogas were reducing expenditure on kerosene, reducing dependence on fuel from wood, making the yard clean, pleasing to the eye and reducing odors (Elly, 2012).The management of pig waste into alternative energy was very beneficial for various parties (Mariawan, 2012). Several studies had shown that biogas technology can be applied to household, commercial or village scale. Utilization of biogas as an energy source in small industries based on agricultural product processing can provide multiple effects and become a driving force for the dynamics of rural development.Biogas can also be used to increase added value by giving green labeling to processed products that were processed using green energy. Biogas as an alternative solution to overcome the energy crisis solution (Yahya et al. 2017).

\section{CONCLUSIONS AND SUGGESTIONS}

Based on the results of the study, it can be concluded that the biogas produced is beneficial for minimizing environmental pollution and substituting the use of LPG gas and firewood.Suggestions, biogas reactors need to be socialized to other farmers who develop pig farming businesses in residential areas and need government intervention to introduce biogas reactors because they require investment funds.

\section{ACKNOWLEDGMENTS}

Thank you to the Rector, Chair and Secretary of the LPPM and the Dean of the Faculty of Animal Husbandry UNSRAT, who gave the author the opportunity to obtain research funding through SKIM RTUU.

\section{REFERENCES}

[1] Adl, M., K.C. Sheng., Y.H. Xia., A. Gharibi and X. Chen. 2012. Examining a Hybrid Plug-Flow Pilot Reactor for Anaerobic Digestion of Farm-Based Biodegradable Solids. Int. J. Environ. Res., 6(1): 335-344.

[2] Aku, A.S., T. Saili and Amiruddin. 2013. Distribution, Population Structure and Reproductive Performance of Local Pigs in Tinangge District, South Konawe Regency. Journal of Agriplus, 23 (03): 188-192.

[3] Barnhart, S. 2012. Teaching Sustainability across Scale and Culture: Biogas in Context.Journal of Sustainability Education 3.

[4] BPS North Sulawesi. 2020. North Sulawesi in Figures 2020. Statistics Agency of North Sulawesi, Manado.

[5] Dewi, R.P and M. Kholik. 2018. Study of Potential Utilization of Biogas as an Alternative Energy Source in the Magelang Region. Journal of Mechanical Engineering, 2(1): 8-14.

[6] Elly, F.H. 2012.Training Programme Biogas to Minimize Environmental Pollution in Tempok Village Sub Tompaso District.Proceeding : The $2^{\text {nd }}$ International Seminar on Animal Industry 2012 (ISAI) Faculty of Animal Science Bogor Agricultural University.

[7] Gobai, F., Hartoko and Rachmawati. 2013. The Relationship between Laying Period with Litter Size and Birth Weight of Piglets in Pig Breeding Company, Kedungbenda, Kemangkon Purbalingga. Scientific Journal of Animal Husbandry, 1 (3) : 1114-1119.

[8] Ministry of Agriculture. 2012. Guidelines for the Implementation of Environmentally Friendly Pig Farming Business Arrangements. Department of Agriculture, Jakarta.

[9] Mariawan, I.M. 2012. IbM Biogas. Journal of Community Service. Widya Laksana, January 2012 Edition: 37-44.

[10] Putra, I.K.A., N. Karnaningroem, and M. A. Mardyanto. 2015. Design of Pig Farm Liquid Waste Treatment Building and Reuse of Processing Results. Journal of ITS Engineering, 4 (1) : 1-5.

[11] Salendu, A.H.S and F.H. Elly. 2017. Sustainable Pig Farming Group PKM. PKM report. LPPM, UNSRAT.

[12] Saroinsong, T, A. N. Mekel, F. Luntungan, and M. Budiman. 2019. Optimization of Pig Farmer Productivity in North Sulawesi through the Design of Automatic Animal Feeding Machines. JTT (Journal of Applied Technology), 5 (1) : 33-36.

[13] Seseray, D.Y.S., S. Triatmojo and A. Pertiwiningrum. 2012. Utilization of Pig Feces (Sus sp.) as a Source of Biogas with the Addition of Sago Dregs (Metroxylon spp.) at C/N Ratio Level. Animal Husbandry Bulletin 36 (3) : 6674.

[14] Sobang, Y. U.L and C. A. Paulus. 2017. Contribution of Pig Farming to Fisherman's Household Income in Nembrala Village, West Rote District, Rote Ndao Regency. Journal of Animal Husbandry Nucleus, 4 (1) : 89 - 94.

[15] Suarna, I.W and N.N. Suryani. 2015. Opportunities and Challenges for Pig Livestock Development in Gianyar Regency, Bali Province. Animal Science Magazine, 18 (2) : 61-64. 
[16] Suryadi, I.M.A., L.E. Tripolupi and K.R. Suwena. 2014. Feasibility Analysis of Sancaya Pig Livestock Business in terms of the NPV Method in Banjar Ponggang, Payangan, Gianyar. Department of Economics Education, Faculty of Economics and Business, Ganesha University of Education, Singaraja, Indonesia.

[17] Takarenguang, E.J., J. E.M. Soputan., V. R. W. Rawung, and J.A.D. Kalele. 2018. Utilization of Pig Breed Waste as a Biogas Producer. Journal of Zootek, 36 (1) : 113 - 122.

[18] Tulak, A., Khaerunnisa and Landius. 2018. Pig Farming Development Strategy in Hbukiok District, Jayawijaya Regency. Optimal Journal II, 91-102.

[19] Wahyuni, S. 2011. Biogas Renewable Energy was Environmentally Friendly and Sustainable. 10th National Science Congress (KIPNAS).8-10 Nov, Jakarta.

[20] Wahyuni. 2015. Biogas Practical Guide. Swadaya Publisher, Jakarta.

[21] Wea, E.D.N., M. Y. Luruk and U. R. Lole. 2020. Silver Program Pig Livestock Business Development Strategy in Ngada Regency. Indonesian Animal Husbandry Journal (JPI), 22(2):218-227.

[22] Yahya, Y., Tamrin and S. Triyono. 2017. Production of Biogas from a Mixture of Chicken Manure, Cow Manure, and Mini Elephant Grass (Pennisetum Purpureum Cv. Mott) With Batch System. Journal of Agricultural Engineering Lampung 6 (3) : 151-160. 